\title{
The Effect of Additives in Urine Tubes on Biochemical Analytes
}

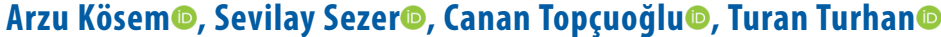

Ankara Numune Training and Research Hospital, Clinical Biochemistry Laboratory, Ankara, Turkey

Arzu Kösem, M.D.

Sevilay Sezer, M.D.

Canan Topçuoğlu, M.D.

Turan Turhan, M.D.

*This manuscript presented at Preanalytical Stage Symposium, Abant- Bolu, Turkey, 25-26 March 2016

\section{Correspondence:}

M.D. Arzu Kösem

Ankara Numune Training and Research Hospital, Clinical Biochemistry Laboratory, Ankara, Turkey

Phone: +903125084436

E-mail: arzukosem@gmail.com

Received : March 10, 2019

Revised : September 12,2019

Accepted : September 12, 2019

\section{ABSTRACT}

Purpose: The use of urine tubes containing preservatives for urine analysis has made a new era. Compounds in tubes with preservatives can be listed as follows: Sodium propionate (94\%), ethylparaben $(5.6 \%)$ and chlorhexidine ( $0.4 \%)$. The aim of this study was to test the effectiveness of urine tubes with preservative (BectonDickinson, Franklin Lakes, USA) on some biochemical parameters.

Patients and Methods: The 24-h urine samples ( $n=118$ ) obtained from the outpatient clinic were sent for routine urine analysis. Urine samples were divided into two tubes; urine tubes with preservatives and urine tubes without preservatives. Six biochemical parameters (protein, calcium, urea, phosphorus, creatinine, microalbumin) were measured on a Beckman Coulter AU680 analyzer.

Results: The results of the phosphorus in the two urine samples were decreased significantly at all time points in the stability studies $(p=0.02, p<0.01)$.

Conclusion: It can be concluded that tubes containing preservatives could be used to analyze biochemical parameters. However, measurement of urine phosphorus with tubes containing preservatives should be performed immediately after delivery to the laboratory.

Keywords: Additive, biochemical test, stability, urine tube; urine

\section{IDRAR TÜPLERINDEKI KATKI MADDELERININ BIYOKIMYASAL ANALITLERE ETKISI}

ÖZET

Amaç: İdrar analizi için koruyucu içeren idrar tüplerinin kullanılması yeni bir dönem olmuştur. Koruyucu içeren tüplerdeki bileşikler şu şekilde sıralanabilir: Sodyum Propiyonat $(\% 94)$, etilparaben $(\% 5,6)$ ve klorheksidin $(\% 0,4)$. Biz çalışmamızda koruyucu içeren idrar tüplerinin (Becton-Dickinson, Franklin Lakes, USA) bazı biyokimyasal parametreler üzerine etkisini incelemeyi amaçladık.

Hastalar ve Yöntem: 24 saatlik idrar örnekleri $(n=118)$, poliklinikten rutin idrar analizi için gönderilen örneklerden elde edildi. İdrar örnekleri 2'ye porsiyonlandı: Koruyucu içeren tüpler ve katkı maddesi içermeyen tüpler. Altı biyokimya parametresi (protein, kalsiyum, üre, fosfor, kreatinin, mikroalbümin) Beckman Coulter AU680 analizöründe analiz edildi.

Bulgular: İki idrar örneğindeki fosforun sonuçları stabilite çalışmalarında tüm zaman noktalarında anlamlı olarak azaldı $(p=0,02, p<0,01)$.

Sonuç: Biyokimyasal parametreleri analiz etmek için koruyucu içeren tüplerin kullanılabileceği sonucuna varabiliriz. Ancak, koruyucu içeren tüplerle idrar fosfor ölçümü laboratuvara teslim edildikten hemen sonra yapılmalıdır.

Anahtar sözcükler: Katkı maddesi, biyokimyasal test, stabilite, idrar tüpü, idrar 
$\mathrm{n}$ these times, the use of central laboratories is becoming more widespread and samples are transported from health centers to central laboratories for testing. This situation increases the importance of sample transport in the pre-analytical phase. The pre-analytical phase includes biological specimen collection, identification, storage and transport process of the sample (1). Urine analysis plays a key role in the differential diagnosis of many renal and urological disorders (2). However, urine is a very unstable sample. Alkaline $\mathrm{pH}$, low relative density and low osmolality can induce rapid lysis of some urine particles after collection (3). The time between the collection of a urine sample and performing a urine analysis test should be short. If the sample storage under refrigeration and the analysis can be performed within 24 hours, no preservatives are needed for many chemical analytes which are evaluated with test strips. However, if a delay cannot be avoided and refrigeration is not possible, urine collection containers prefilled with the preservative solution are used to preserve urine samples (3).

The addition of preservatives to the containers usually prevents metabolic changes of urine from bacterial overgrowth. Urinary preservatives $(\mathrm{HCl}, \mathrm{NaHCO} 3$, boric acid, chlorhexidine, etc.) are used for different reasons (to increase solubility, to prevent bacterial growth, stability of metabolites, etc.) (4). The preservatives may be influenced by some enzymatic reactions (3). The choice of the preservatives should be based on the analytical measurement. The use of boric acid affects a number of test strip reactions. The use of boric acid makes the urine $\mathrm{pH}$ acidic and is associated with false-negative strip test results (e.g. protein, white blood cells and ketones) (4). Ethanol (50\%) is selected for the protection of cellular particles, nevertheless, red and white blood cell lysis, which are only partially inhibited, is observed. The addition of polyethylene glycol $(20 \mathrm{~g} / \mathrm{L})$ to the ethanol fixative (Saccomanno's fixative) increases the quality of the protection.

We also worked with urine additives in the urine tubes to test the effect on some biochemical tests. It has been suggested that for the most frequently requested markers such as $\mathrm{Ca}^{2+}$ and $\mathrm{PO}_{4}{ }^{3-}$, acid preservatives are recommended in order to prevent salt precipitation of calcium and phosphate. Therefore, particularly for $\mathrm{Ca}^{2+}$ and $\mathrm{PO}_{4}^{3-}$ measurements, the fact if they were stable for up to 48 hours was tested. No studies have been conducted on the effect of the preservatives in determining biochemical assays measured by a spectrophotometric method.

\section{Materials and methods}

24-h urine samples of 118 outpatients who applied to our hospital were obtained. The urine samples were divided into two tubes; urine tubes with preservatives and urine tubes without preservatives. BD Vacutainer Urinalysis Preservative Plus Urine Tubes (Becton-Dickinson, Franklin Lakes, NJ, USA) contains $94 \%$ sodium propionate (340 $\mathrm{mol} /$ tube), $5.6 \%$ ethylparaben, $0.4 \%$ para-hydroxybenzoic acid ethyl ester ( $8.11 \mathrm{~mol} /$ tube) and chlorhexidine diacetate $(0.22 \mathrm{~mol} /$ tube). Protein, calcium, urea, phosphorus, creatinine, microalbumin in these samples were determined in a Beckman Coulter AU680 analyzer with the original reagents (Beckman Coulter, Indianapolis, IN). Reportable range provided by the manufacturer was Analytical Measurement Range: $4-200 \mathrm{mg} / \mathrm{dL}, 0.8-30 \mathrm{mg} /$ $\mathrm{dL}, 112-5600 \mathrm{mg} / \mathrm{dL}, 3.41-285 \mathrm{mg} / \mathrm{dL}, 1.10-610.00 \mathrm{mg} /$ $\mathrm{dL}, 2.0-400.0 \mathrm{mg} / \mathrm{L}$ for protein, calcium, urea, phosphorus, creatinine, microalbumin, respectively. Between-day imprecision (coefficients of variation, CVs) of our laboratory are: $3.22 \%$ for Protein, $2.06 \%$ for calcium, $2.64 \%$ for urea, $2.88 \%$ for phosphorus, $2.91 \%$ creatinine and $4.04 \%$ for microalbumin.

$\mathrm{Ca}^{2+}$ and $\mathrm{PO}_{4}^{3-}$ measurements in spot urine samples containing preservatives tubes were repeated at three different time points during the study: at the time of sampling $(0 \mathrm{~h}), 24 \mathrm{~h}$ after each sampling, and again after $48 \mathrm{~h}$ by keeping at $+4^{\circ} \mathrm{C}$. Ethical approval was obtained from the Ankara Numune Training and Research Hospital Ethical Committee (2017/E120400), Turkey.

\section{Statistical analysis}

kolmogorov-Smirnov test was applied to test for a normal distribution. The Bland-Altman plot and PassingBablok linear regression statistics were used to compare biochemical parameters which were analyzed with tubes that contain preservatives and tubes that did not contain preservatives. MedCalc (ver. 14.12.0) statistical software was used for all calculations. The paired t-test was used to evaluate repeated measures using SPSS for Windows version 13.0 software program (SPSS Inc., Headquarters, Chicago, Illinois, USA). The $p$-values $\leq 0.05$ were considered statistically significant.

\section{Results}

Table 1 shows the mean \pm SD or median (IQR) of the urinary parameters of the tubes with preservatives and without preservatives. The paired t-test shows no significant standard deviation between the two tubes for the levels of protein, urea, phosphorus, creatinine, calcium and microalbumin ( $p=0.79, p=0.10, p=0.16, p=0.78, p=0.24, p=0.79$, respectively) (Table 1 ). No significant differences were 


\section{Table 1. Preservative plus urine tube and additive-free tube results}

\section{Analytes}

PROTEIN (MEDIAN (IQR)), mg/dL

CALCIUM (MEDIAN (IQR)), mg/dL

MICROALBUMIN(MEDIAN $\pm(I Q R)), \mathrm{mg} / \mathrm{dL}$

URE A(MEAN $\pm S D), \mathrm{mg} / \mathrm{dL}$

PHOSPFORUS (MEAN $\pm S D$ ), $\mathrm{mg} / \mathrm{dL}$

CREATININ(MEAN $\pm S D$ ), $\mathrm{mg} / \mathrm{dL}$

$\mathrm{pH}(\mathrm{MEAN} \pm \mathrm{SD})$

\section{Preservative Plus Urine Tubes}

$14.25(4.15-49.5)$

$7.42(2.42-8.50)$

$1.57(0.39-14.82)$

$933.23 \pm 476.71$

$33.7 \pm 20.52$

$55.60 \pm 26.95$

$5.95 \pm 0.138$

\begin{tabular}{cc} 
Additive-Free Tubes & $\boldsymbol{P}$ \\
\hline $48.10(34.70-72.02)$ & 0.79 \\
$6.93(2.42-8.37)$ & 0.24 \\
$1.74(0.40-13.89)$ & 0.79 \\
$907.09 \pm 471.62$ & 0.10 \\
$33.07 \pm 19.96$ & 0.16 \\
$54.78 \pm 26.43$ & 0.78 \\
$5.5 \pm 0.197$ & 0.001
\end{tabular}

Table 2. Stability study results

Analytes

PHOSPFORUS

CALCIUM
Unite

$\mathrm{mg} / \mathrm{dL}$

$\mathrm{mg} / \mathrm{dL}$

$\begin{array}{cc}n & \text { Oh } \\ 11 & 28.54 \\ 11 & 7.042\end{array}$

7.042
$24 \mathrm{~h}(+/-95 \% \mathrm{Cl})(\mathrm{p})$

$-1.70(-2.55 /-0.84)(0.02)$ *

$-0.0857(-0.295 / 0.124(0.356)$
$48 \mathrm{~h}(+/-95 \% \mathrm{Cl})(\mathrm{p})$

$-1.86(-2.43 /-1.28)(0.00)$ *

$0.0571(-0.148 / 0.262(0.522)$ determined between the values obtained from the different measurements for $\mathrm{Ca}^{2+}$ in stability studies. But the levels of $\mathrm{PO}_{4}^{-3}$ values in three urine samples were decreased significantly in all of the time points $(p=0.02, p<0.01)$ (Table 2).
The Bland-Altman plot showed that the different tubes had an influence on the mean of protein, urea, phosphorus, creatinine, calcium and microalbumin values in our results (Figure 1).

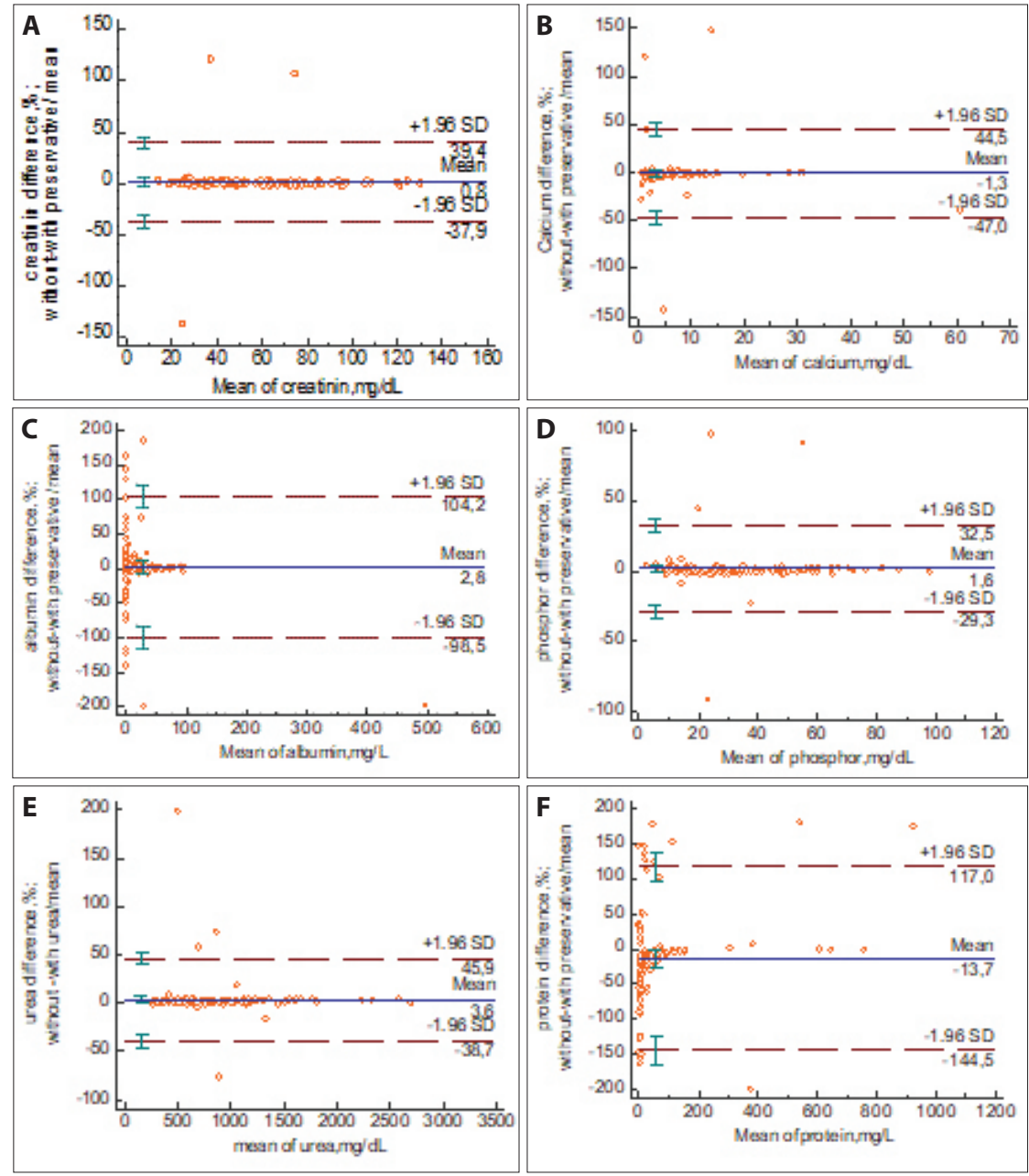

Figure 1. Bland-Altman difference plot between without preservative tube and with preservative tubes for; creatinin (a); calcium (b); albumin (c); phosphor (d); urea (e); protein (f). 
The Bland-Altman difference plots demonstrated high values for protein, microalbumin (Additive-free tubes-preservative urine tubes) and low values for calcium, urea, phosphorus, creatinine (Additive-free tubes-preservative urine tubes). Passing-Bablok regression analysis (Figure 2) showed all analytes.

\section{Discussion}

Preservatives interfere with enzymatic measurements; therefore, preservation may be critical. Urine analysis is very important in the diagnosis and monitoring of kidney diseases. Urine analysis consists of microscopic and chemical investigation. Pre-analytical factors are particularly important by the analysis of urine $(3,4)$. Urine preservatives prevent bacterial growth (4-5). Alkaline $\mathrm{pH}$ could increase the lysis of urine particles. Preservatives could affect chemical properties (3-6). In our study, urine preservatives were found no effects on urine urea, phosphorus, calcium, creatinine, protein and microalbumin tests in the preservatives plus urine tubes.

We also found that urine collection without preservatives did not cause any difference in protein, urea, phosphorus, creatinine, calcium and microalbumin $(p=0.79, p=0.10$, $p=0.16, p=0.78, p=0.24, p=0.79$, respectively). In present, automated analyses in laboratories lead to a decrease in the time of analyses and duration of storage. Most laboratories assay 24-h urine samples easily and promptly after delivery to the laboratory. Thus, the incidence of clinically significant errors in the assessment of analytes excretion
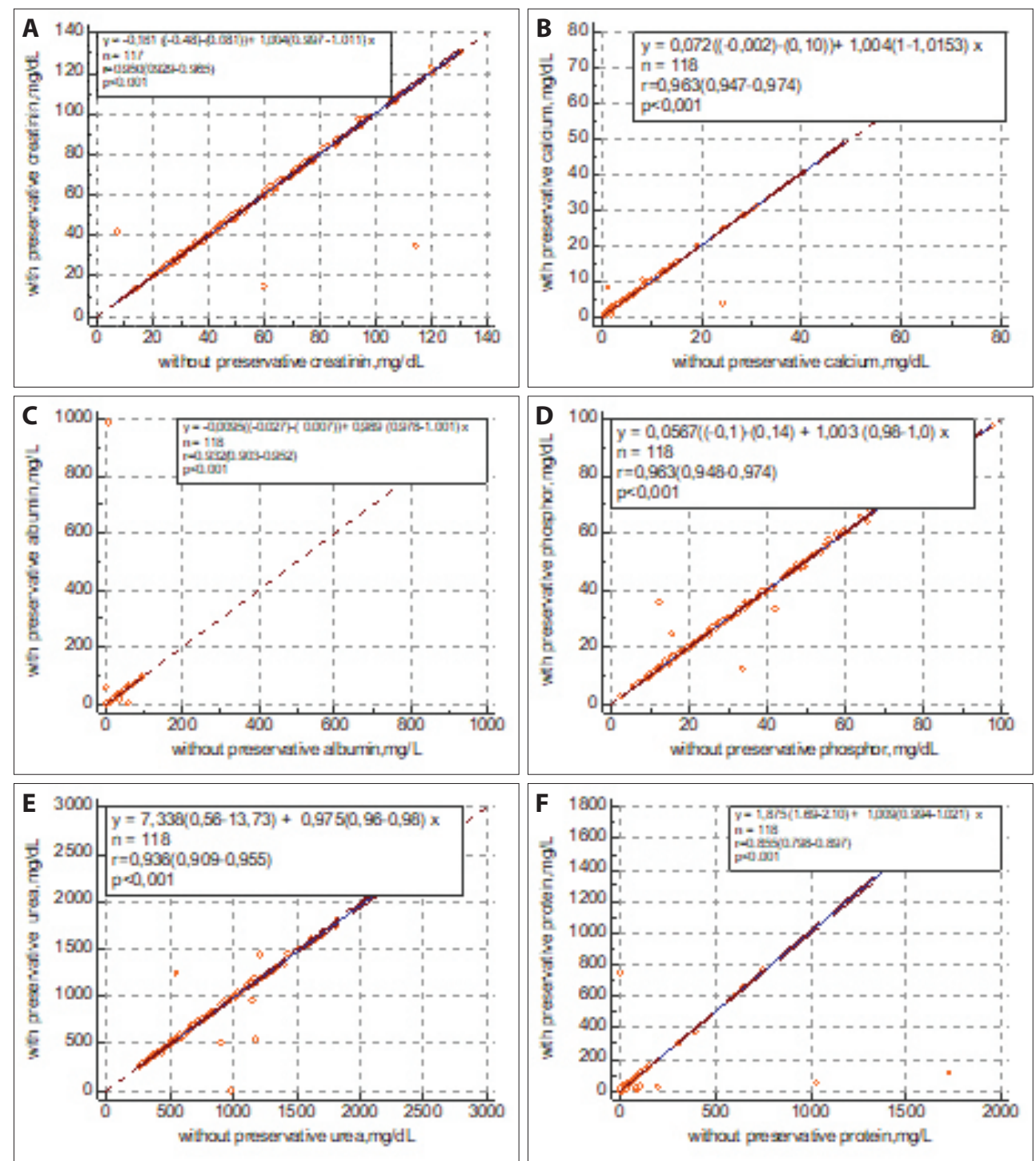

Figure 2. Passing-Bablok regresyon analysis. Results comparison between without preservative tube and with preservative tubes for; creatinin (a); calcium (b); albumin (c); phosphor (d); urea (e); protein (f). 
from urine collected without preservative is partly dependent on how long the samples were stored before analysis.

There are few studies in the literature on the effect of urine preservatives on biochemical parameters. Lojo and colleagues (2016) reported that urine protectants have no effect on protein and microalbumin in their studies. In this study, the urine protein nephelometric method and microalbumin tests were performed by the immunonephelometric method (7). In our study, urine protein was measured by the pyrogallol red-molybdate method. However, we found the same results with them. As has been emphasized before, there are few studies in the literature which are aimed to investigate the effects of additives on some biochemical tests in urine samples. Therefore, some further evaluations should be planned.

\section{References}

1. Coppens A, Speeckaert M, Delanghe J. The pre-analytical challenges of routine urinalysis. Acta Clin Belg 2010;65:182-189. [CrossRef]

2. Fogazzi GB, Cameron JS, Ritz E, Ponticelli C. The history of urinary microscopy to the end of the 19th century. Am J Nephrol 1994;14:452-7. [CrossRef]

3. Delanghe J, Speeckaert M. Preanalytical requirements of urinalysis. Biochem Med (Zagreb) 2014;24:89-104. [CrossRef]

4. Yilmaz G, Yilmaz FM, Hakligör A, Yucel D. A preservatives necessary in 24-hour urine measurements? Clin Biochem 2008:41;899-901. [CrossRef]
The present study had some limitations. Only preservative tubes were stored at $4^{\circ} \mathrm{C}$ for two days. But additive-free tubes were analyzed promptly after delivery to the laboratory and not stored at $4^{\circ} \mathrm{C}$ or at room temperature. Therefore, the data in our study is not sufficient to discuss the effect of the storage temperature. Nevertheless, it seems that the decrease of $\mathrm{PO}^{3-}$ concentrations which kept at $+4^{\circ} \mathrm{C}$ were measured at different time points have the highest/a higher tendency for precipitation.

In conclusion, no differences were found between the results obtained from both types of tubes and we found that it did not affect the levels of urinary $\mathrm{Ca}^{2+}$ and $\mathrm{PO}_{4}{ }^{3-}$ if the samples were assayed promptly after delivery to the laboratory.

5. Fogazzi GB, Verdesca S, Garigali G. Urinalysis: Core Curriculum 2008. Am J Kidney Dis 2008;51:1052-67. [CrossRef]

6. Eisinger SW, Schwartz M, Dam L, Riedel S. Evaluation of the BD vacutainer plus urine $C \& S$ preservative tubes compared with nonpreservative urine samples stored at $4^{\circ} \mathrm{C}$ and room temperature. Am J Clin Pathol 2013;140:306-13. [CrossRef]

7. Lojo SA, Soto S, Lojo-Luaces N.Validation of the Vacutainer ${ }^{\oplus}$ urinalysis preservative plus urine tube for the determination of albumin and protein. Clin Chem Lab Med 2016;54(9):e253-4. [CrossRef] 